\title{
PENANGGULANGAN GIZI BURUK PADA DOKTER DAN PETUGAS GIZI PUSKESMAS DI DINAS KESEHATAN KABUPATEN TANAH DATAR
}

\author{
${\text { Helmizar }{ }^{1 *} \text {, Susmiati }}^{2)}$, Asrawati Nurdin ${ }^{3)}$, Hafifatul Auliya Rahmy ${ }^{1)}$, Restu Sakinah'), \\ Rani Wahyuni ${ }^{1)}$, Serly Suryana ${ }^{1)}$, Monika Trijuli Astuti ${ }^{1)}$, dan Meicy Astuti ${ }^{1)}$ \\ ${ }^{1)}$ Fakultas Kesehatan Masyarakat Universitas Andalas \\ 2) Fakultas Keperawatan Universitas Andalas \\ 3) Fakultas Kedokteran Universitas Andalas \\ *)Email: eelbiomed@gmail.com
}

\begin{abstract}
ABSTRAK
Gizi buruk merupakan salah satu masalah gizi yang ditentukan berdasarkan indikator antropometri berat badan menurut tinggi atau panjang badan (BB/TB) dengan z-skor BB/TB $<-3$ SD dan ada atau tidaknya odema. Masalah gizi buruk banyak terdapat di negara miskin dan berkembang seperti negara Indonesia. Berdasarkan Profil Kesehatan Indonesia Tahun 2015, sebanyak 26.518 Balita mengalami gizi buruk dengan prevalensi gizi buruk sebanyak 3,8\% di Indonesia. Penanganan masalah gizi yang ada saat ini, tidak bisa hanya oleh pemerintah saja, namun perlu keterlibatan dan dukungan dari pemangku kepentingan lain seperti unsur perguruan tinggi. Tujuan kegiatan ini adalah untuk meningkatkan pengetahuan dokter dan petugas yang bekerja di Puskesmas se Kabupaten Tanah Datar dalam penanggulangan gizi buruk. Metode yang digunakan adalah pelatihan (capacity building). Pelatihan diberikan kepada stake holder Puskesmas tentang upaya peningkatan status gizi anak melalui kelas ibu balita, pengukuran status gizi anak yang mengikuti posyandu, pemberian edukasi gizi bagi ibu balita melalui kelas ibu balita dan pemantauan asupan gizi dan gizi balita. Sasaran utama dalam pelaksanaan kegiatan ini adalah dokter, petugas gizi dan petugas KIA seluruh puskesmas yang ada di Kabupaten Tanah Datar. Dari kegiatan ini diharapkan dapat meningkatkan pengetahuan tenaga kesehatan dalam penanggulangan stunting di wilayah Kabupaten Tanah Datar. Terjadi peningkatan pengetahuan petugas kesehatan dengan rata-rata nilai pre-test 8,9 meningkat menjadi 9,3 pada post test. Dengan adanya kegiatan ini maka diharapkan dapat menurunkan angka gizi buruk dan kematian pada anak dimulai dari lingkup wilayah Kabupaten Tanah Datar.
\end{abstract}

Kata Kunci : gizi buruk, penanggulangan, petugas kesehatan

\section{Prevention of Malnutrition for Doctors and Medical Staff Specialized in Nutrition at Tanah Dasar Regency}

\begin{abstract}
Malnutrition is a nutritional problem determined based on anthropometric indicators of body weight according to height or body length (BW / TB) with a z-score of <-3 SD and the presence or absence of edema. There are many problems with malnutrition in poor and developing countries such as Indonesia. Based on the 2015 Indonesian Health Profile, as many as 26,518 toddlers suffer from malnutrition, with a prevalence of $3.8 \%$ malnutrition in Indonesia. The current management of nutrition problems cannot only be handled by the government but requires the involvement and support of other stakeholders, such as elements of higher education. This activity aims to increase the knowledge of doctors and officers who work in Puskesmas throughout Tanah Datar Regency in overcoming malnutrition. The method used is training (capacity building). The training was given to Puskesmas stakeholders on efforts to improve children's nutritional status through mothers under five classes, measuring the nutritional status of children attending posyandu, providing nutrition education for mothers under five through mothers under five classes, and monitoring nutritional and nutritional intake
\end{abstract}


of children under five. The main targets in implementing this activity are doctors, nutrition officers, and $\mathrm{MCH}$ officers in all puskesmas in Tanah Datar District. This activity is expected to increase health workers' knowledge in overcoming stunting in the Tanah Datar district. There was an increase in health workers' knowledge with an average pre-test score of 8.9, increasing to 9.3 in the post-test. With this activity, it is hoped that it can reduce malnutrition and mortality in children starting from the Tanah Datar district's scope.

Keywords: malnutrition, prevention of malnutrition, doctors, medical staff, Tanah Datar regency

\section{PENDAHULUAN}

Rendahnya status gizi masyarakat sosial yang dihadapi Indonesia merupakan masalah sosial di masyarakat yang akan berdampak pada kualitas sumber daya manusia, karena akan mempengaruhi kecerdasan, daya tahan tubuh terhadap penyakit, kematian bayi, kematian ibu dan produktivitas kerja. Stunting adalah masalah kurang gizi kronis yang disebabkan oleh kurangnya asupan gizi dalam waktu yang cukup lama, sehingga mengakibatkan gangguan pertumbuhan pada anak yakni tinggi badan anak lebih rendah atau pendek (kerdil) dari standar usianya (Depkes, 2018).

Masalah gizi stunting banyak terdapat di negara miskin dan berkembang seperti negara Indonesia. Berdasarkan data Riset Kesehatan Dasar (Riskesdas) tahun 2010 diketahui bahwa prevalensi balita stunting mencapai 35,6\% dan mengalami peningkatan pada tahun 2013 yaitu 37,2\%. Prevalensi stunting tersebut lebih tinggi dibandingkan angka prevalensi gizi kurang dan buruk $(17,9 \%)$, balita kurus $(13,3 \%)$ serta balita gemuk (14\%). Masalah kesehatan masyarakat dianggap berat bila prevalensi pendek sebesar 30 - 39 persen dan serius bila prevalensi pendek (Riskesdas 2010, 2013).

Prevalensi stunting di Sumatera Barat menurut Riskesdas tahun 2010 adalah $32,7 \%$ angka ini juga menunjukkan peningkatan pada tahun 2013 yaitu 39,2\% sedangkan di Kabupaten Tanah Datar prevalensi balita stunting adalah 38,8\%. Sedangkan berdasarkan hasil studi "Efek Jangka Panjang Pemberian Suplementasi Gizi Dan Stimulasi Psikososial Terhadap Tumbuh Kembang Anak Usia 5 Tahun Di Kabupaten Tanah Datar Tahun 2017" juga ditemukan masih tingginya prevalensi anak stunting sebesar 43,18\%. Hal ini menunjukkan Provinsi Sumatera Barat termasuk salah satu dari 20 provinsi yang prevalensi balita stunting diatas prevalensi nasional (Helmizar, 2017).

Kejadian gizi buruk di Kabupaten Tanah datar menurut data PSG tahun 2017 bersifat fluktuatif, dimana pada tahun 2015 sebanyak 2,1\% anak mengalami gizi buruk, pada tahun 2016 menurun menjadi $0,3 \%$ dan kembali meningkat menjadi $2,3 \%$ pada tahun 2017 (PSG, 2017).

Tatalaksana penanggulangan gizi buruk perlu diketahui oleh dokter dan petugas gizi serta KIA yang bertugas di Puskemas khususnya di Kabupaten Tanah Datar agar setiap anak yang mengalami gizi buruk dapat mendapatkan penanganan yang cepat dan tepat oleh dokter dan petugas di Puskesmas.

Berdasarkan uraian diatas masih tingginya masalah gangguan status gizi, maka penulis perlu melakukan kegiatan ini berupa pelatihan penanggulangan gizi buruk pada dokter dan petugas gizi Puskesmas di Dinas Kesehatan Kabupaten Tanah 
Datar.

Kegiatan ini dilakukan dengan memberikan pelatihan kepada dokter dan petugas puskesmas dalam menangani kasus gizi buruk. Pelatihan ini dipandang sangat perlu karena masih banyaknya kejadian gizi buruk yang belum ditangani dengan tepat di puskesmas yang akan menyebabkan tingginya angka kejadian kematian pada anak di Indonesia khususnya di Kabupaten Tanah Datar. Kegiatan ini sejalan dengan upaya pemerintah dan upaya global dari berbagai negara dalam rangka mempercepat perbaikan gizi pada 1000 Hari Pertama Kehidupan (HPK) atau yang disebut dengan Scaling Up Nutrition (SUN) dan di Indonesia disebut dengan Gerakan Nasional 1000 Hari Pertama Kehidupan. Penanganan masalah gizi yang ada saat ini, tidak bisa hanya oleh pemerintah saja, namun perlu keterlibatan dan dukungan dari pemangku kepentingan lain seperti unsur perguruan tinggi. Kontribusi berupa ilmu dan teknologi yang ada di perguruan tinggi dapat diterapkan di masyarakat untuk mengatasi permasalahan yang ada khususnya masalah gizi buruk pada anak.

Tujuan kegiatan ini adalah untuk meningkatkan pengetahuan dokter dan petugas yang bekerja di Puskesmas se Kabupaten Tanah Datar dalam penanggulangan gizi buruk. Diharapkan kegiatan ini akan memberi manfaat bagi mitra dan pelaksana. Pertama bagi mitra, setelah pelaksanaan kegiatan mitra mengalami peningkatan pengetahuan dan peningkatan kapasitas tenaga kesehatan dalam penanganan anak gizi buruk. Kedua bagi pelaksana, bagi dosen sebagai sarana dan upaya melakukan kegiatan sebagai partisipasi aktif dan mengaplikasikan ilmunya, bagi perguruan tinggi sebagai wujud pelaksanaan Tri darma Perguruan Tinggi.

\section{METODE}

Salah satu cara untuk mengurangi kejadian gizi buruk dan meningkatkan status gizi anak dilakukan secara terintegrasi melibatkan stake holder terkait dan mobilisasi masyarakat. Oleh karena itu diperlukan pendampingan pada petugas kesehatan (puskesmas) memperdayakan masyarakat dan dalam upaya-upaya program yang terkait untuk kesehatan anak melalui kegiatan: Pemberian pelatihan (capacity building) bagi stake holder Puskesmas tentang upaya peningkatan status gizi anak melalui kelas ibu balita, pengukuran status gizi anak yang mengikuti posyandu, pemberian edukasi gizi bagi ibu balita melalui kelas ibu balita dan pemantauan asupan gizi dan gizi balita. Sasaran utama dalam pelaksanaan kegiatan ini adalah dokter, petugas gizi dan petugas KIA seluruh puskesmas yang ada di Kabupaten Tanah Datar.

Tahapan dalam kegiatan ini adalah sebagai berikut:

Pertama : Melakukan pendekatan dengan aparat Dinas Kesehatan untuk teknis pelaksanaan pelatihan bagi dokter dan petugas gizi dalam penanggulangan gizi buruk. Melakukan pendekatan dengan petugas Puskesmas dalam hal pemberian surat tugas untuk mengikuti kegiatan pelatihan bagi dokter dan petugas gizi.

Kedua : Melakukan pembuatan buku pedoman untuk pelatihan penanggulangan gizi buruk bagi dokter dan petugas gizi yang disempurnakan kembali untuk digunakan sebagai panduan untuk dokter dan petugas puskesmas dalam menanggulangi gizi buruk. 
Ketiga : Melakukan pretest kepada seluruh dokter dan petugas puskesmas yang hadir pada kegiatan pelatihan, melakukan pelatihan bagi dokter dan petugas puskesmas dengan materi penatalaksanaan penanggulangan gizi buruk dan ANC terpadu untuk tenaga puskesmas, stimulasi Manjujai untuk penanggulangan stunting, diagnosis balita gizi buruk/stunting dan penatalaksanaan MTBS, dan penatalaksanaan gizi (formula WHO) untuk penderita gizi buruk dengan menggunakan buku pedoman pelatihan yang sudah di siapkan sebelumnya.

Keempat : Melakukan post test untuk mengetahui peningkatan pengetahuan dokter dan petugas setelah diberikan materi oleh pemateri.

Kelima : Meminta saran dan tindak lanjut terhadap kasus gizi buruk yang masih banyak di masyarakat. Melakukan evaluasi pelaksanaan pelatihan untuk dicari tindak lanjut berikutnya baik berupa intervensi melalui produk maupun intervensi lainnya

\section{HASIL DAN PEMBAHASAN}

Kegiatan yang dilakukan berupa pelatihan untuk dokter dan tenaga gizi untuk Penanggulangan Gizi Buruk di Kabupaten Tanah Datar. Kegiatan ini dilakukan selama 1 hari penuh yaitu pada tanggal 11 November 2019. Peserta yang hadir pada acara pelatihan berjumlah sebanyak 70 orang yang terdiri dari dokter dan petugas gizi puskesmas se Kabupaten Tanah Datar. Kegiatan selanjutnya adalah penyampaian materi tentang pentingnya aspek asupan gizi dan stimulasi untuk pertumbuhan dan perkembangan anak. Aspek asupan gizi di sini mengacu kepada makanan lokal yang diberikan sebagai PMT kepada ibu hamil dan anak yang mengalami gizi buruk untuk mencapai status gizi yang normal kembali. Sedangkan aspek stimulasi mengacu kepada kegiatan stimulasi Manjujai yang sudah jarang dilakukan di Minangkabau. Asupan gizi yang cukup dan adanya stimulasi Manjujai yang diberikan kepada anak akan sangat mempengaruhi pertumbuhan dan perkembangan anak yang bagus.

Selain itu juga dilakukan pelatihan tatacara bagaimana ilmu kedokteran mendiagnosis keadaan fisik anak stunting. Pemeriksaan fisik pada anak gizi buruk dapat dilakukan dengan cara berikut : 1) Apakah anak tampak sangat kurus / edema / pembengkakan kedua kaki, 2) Tanda-tanda terjadinya syok (renjatan) : tangan dan kaki dingin, nadi lemah, dan kesadaran menurun, 2) Suhu tubuh : hipotermia atau demam, 4) Kehausan, 5) Frekuensi pernapasan dan tipe pernapasan : gejala pneumonia atau gejala gagal jantung, 6) Cek berat badan dan tinggi badan atau panjang badan dan disesuaikan dengan buku status gizi, 7) Pembesaran hati dan adanya kekuningan pada bagian putih mata (conjunctiva), 8) Adanya perut kembung, suara usus, dan adanya suara seperti pukulan ada permukaan air, 9) Pucat yang sangat berat terutama pada telapak tangan , 10) Gejala pada mata : Kelainan pada kornea dan konjuctiva sebagai tanda kekurangan vitamin A, 11) Telinga, mulut dan tenggorokan adanya tanda-tanda infeksi, dan 12) Tampilan (konsistensi) dari tinja. 
Di samping itu juga memberikan pelatihan tentang pemberian tatalaksana gizi berupa pembuatan formula (formula WHO) untuk penderita gizi buruk. Begitu juga dengan tatalaksana lain yang diberikan untuk mengobati gizi buruk dari aspek gizi dan asupan. Penjelasan tentang suatu inovasi yang membuat anak mencapai status gizi yang optimal, yaitu dengan melakukan pemberian MP-ASI lokal yang kaya zat gizi, mudah didapatkan dan juga berguna untuk meningkatkan kemandirian ibu dalam memberikan MP-ASI. Salah satu produk MP-ASI lokal yang dimaksud adalah FJKK, merupakan formula MP-ASI yang berbahan dasar jagung, kacang merah, dan kacang kedelai yang diperkaya dadih. Hal ini sudah diperkuat dengan hasil penelitian Helmizar (2015), pemberian MP-ASI menggunakan beberapa formula produk lokal diantaranya menggunakan beras merah, kacang hijau, dan ikan mujair serta lainnya dapat meningkatkan berat badan dan panjang badan anak yang signifikan. Penambahan dadih pada MP-ASI lokal juga dijelaskan sebagai suatu alternatif substitusi sumber probiotik pada makanan bayi serta anak dengan kondisi tertentu.

Dadih merupakan makanan tradisional yang cukup terkenal di Sumatera Barat. Fermentasi susu kerbau ini memiliki banyak kandungan gizi yang sangat diperlukan tubuh, diantaranya mengandung 16 asam amino diantaranya 13 asam amino esensial, dan mengandung vitamin A. Dadih juga mengandung 39,8\% protein, vitamin B dan K. Dadih sangat populer di beberapa kabupaten / kota di Sumatera Barat seperti Agam, Bukittinggi, Solok, Lima Puluh Kota, dan Tanah Datar. Hasil penelitian Helmizar (2019) di Agam dan Tanah Datar, menunjukkan kadar protein dadih yaitu 12,4\% dan kandungan BAL sebesar 4,6x106 cfu/g. Selain itu dadih juga merupakan solusi terbaik bagi penderita intoleransi laktosa.

Selain penjelasan tentang inovasi pada MPASI Lokal juga dijelaskan tentang stimulasi Manjujai dan psikososial dimana diharapkan dapat memperbaiki pola asuh pada anak yang menderita gizi buruk atau stunting di Kabupaten Tanah Datar. Selain itu didapatkan peningkatan pengetahuan peserta sebelum dan sesudah pemberian materi oleh narasumber.

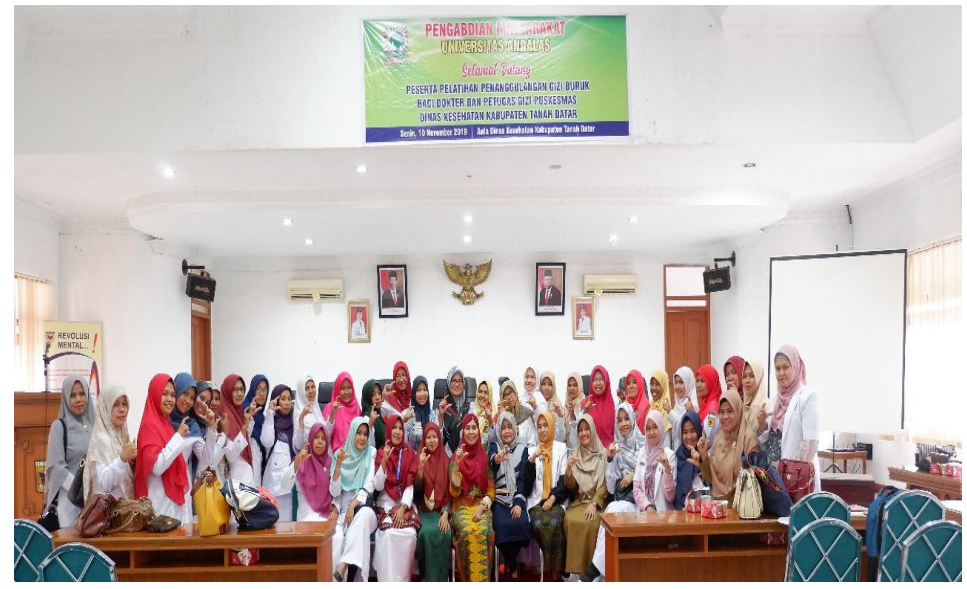

Gambar 1. Foto Bersama dengan Dokter dan Tenaga Pelaksana Gizi Puskesmas Se-Kabupaten Tanah Datar 

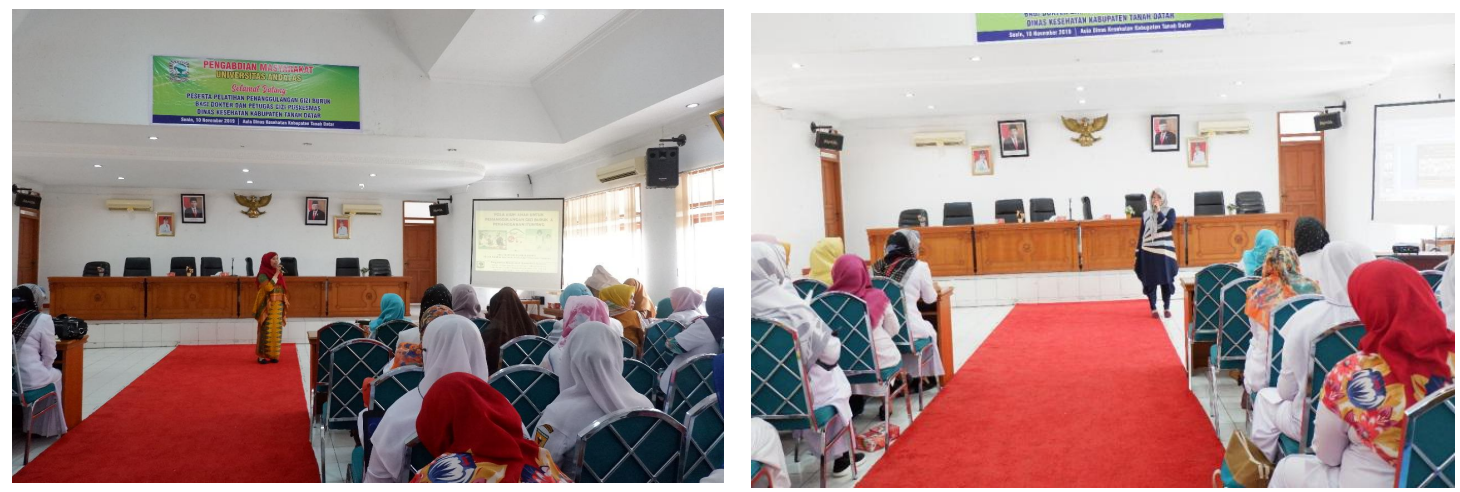

Gambar 2. Penyampaian Materi oleh Narasumber

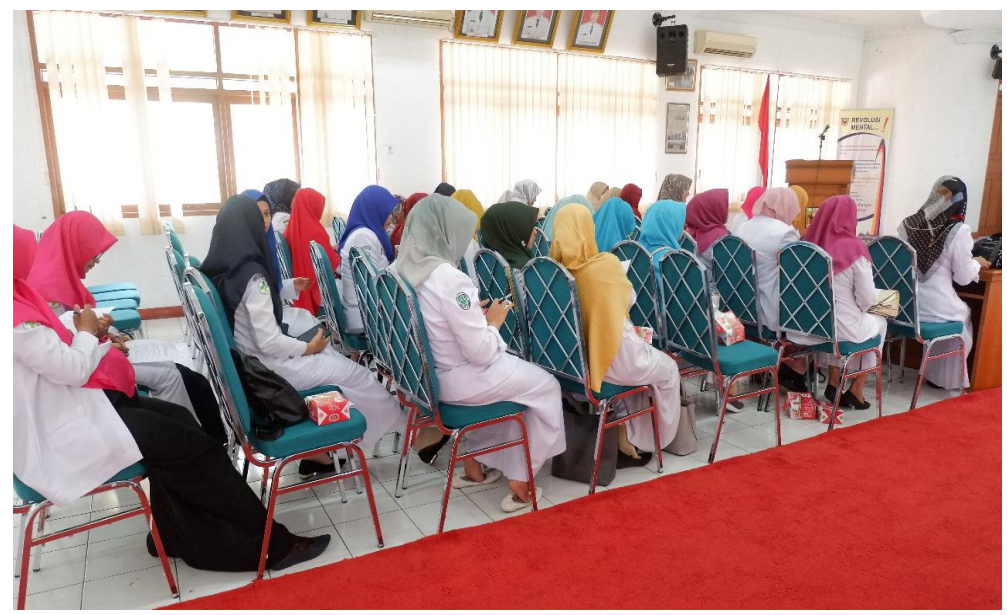

Gambar 3. Peserta Pelatihan Penanganan Anak Gizi Buruk

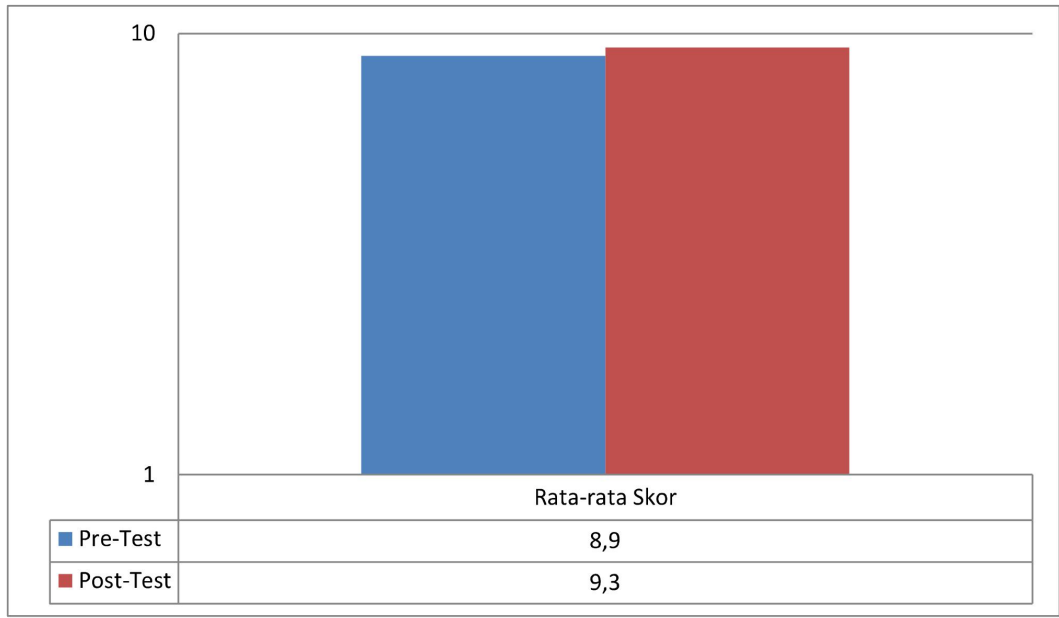

Gambar 4. Hasil Pre-Test dan Post Test Peserta Pelatihan Penanganan anak Stunting 


\section{KESIMPULAN DAN SARAN}

\section{Kesimpulan}

Kegiatan ini dilaksanakan 1 hari di Kantor Bupati Tanah Datar berupa kegiatan pelatihan penanganan anak gizi burik yang diberikan kepada dokter dan tenaga pelaksana gizi puskesmas se Kabupaten tanah datar. Kegiatan mendapat sambutan yang baik dari pihak Dinas Kesehatan Kabupaten Tanah Datar dan terlihat antusias mengikuti kegiatan ini. Selain itu didapatkan pengetahuan dokter dan tenaga pelaksana gizi dalam penanganan anak gizi buruk sebelum dan sesudah pemberian pelatihan.

\section{Saran}

Perlu dilakukan kegiatan tindak lanjut untuk menanggulangi gizi buruk setelah adanya pelatihan untuk dokter dan petugas gizi baik berupa pemberian makanan tambahan yang fungsional dan kaya gizi untuk anak gizi buruk serta pemberian stimulasi berbasis budaya lokal manjujai untuk meningkatkan perkembangan anak.

\section{UCAPAN TERIMAKASIH}

Ucapan terima kasih kepada Universitas Andalas yang telah memfasilitasi dan memberikan dana untuk kegiatan ini.

\section{DAFTAR PUSTAKA}

Afriani, T., dan Y. Seftiadi. 2019. Pemberdayaan Masyarakat melalui Pelatihan Pembuatan Pakan Alternatif Amoniasi Jerami Jagung di Nagari Pelangai Kaciak Kecamatan Ranah Pesisir, Pesisir Selatan. Warta Pengabdian Andalas. 26(2).

Elliyanti A.,Pertiwi D dan Murni AW. 2019. Peningkatan pengetahuan masyarakat terhadap masalah kesehatan pada kelompok berisiko di Nagari Sumanik. Buletin Ilmiah Nagari Membangun. 2(2).

Departemen Kesehatan RI. 2018. Cegah Stunting dengan Perbaikan Pola Makan, Pola Asuh dan Sanitasi.

Departemen Kesehatan RI. 2010. Riset Kesehatan Dasar Provinsi Sumatera Barat. Departemen Kesehatan RI, Jakarta.

Departemen Kesehatan RI. 2013. Riset Kesehatan Dasar Provinsi Sumatera Barat, Departemen Kesehatan RI, Jakarta. 
Putri D.E., Refnandes R., Agustin Y. 2019. Pendidikan kesehatan stimulasi perkembangan anak usia sekolah kepada orangtua. Warta Pengabdian Andalas. 26 (4c).

Helmizar, Resmiati. 2019. Faktor risiko kejadian stunting pada anak usia 3-5 tahun di Kabupaten Tanah Datar Tahun 2018 (a follow-up study): JKMA, Vol 13/Nomor 2/ April-September 2019

Helmizar H, Jalal F, Indrawaty NI, Achadi EL. Local food supplementation and psychosocial stimulation improve linear growth and cognitive development among Indonesian infants aged 6 to 9 months. Asia Pacific Journal of Clinical Nutrition. 2015;26(1):97-103.

Helmizar, Yuswita E, Putra AE. 2019. Analysis of the nutrients and microbiological characteristics of the indonesian dadih as a food supplementation. Global Journal of Health Science, 11(1):155-161.

Helmizar. Putri, A.R, Saputra A. 2018. Membangun nagari fotokopi melalui kuliah kerja nyata revolusi mental Indonesia melayani di Kabupaten Tanah Datar. Buletin Ilmiah Nagari Membangun, 1(3): 78-88

Kemenkes RI. 2018. Riset Kesehatan Dasar, RISKESDAS. Balitbang Kemenkes RI. Jakarta

Roza, E., S.N.Aritonang., H. Susanti dan A.Sandra. 2020. Sanitasi pemerahan dan kualitas susu di kelompok tani harapan makmur di Kecamatan Koto Tangah Kota Padang. Jurnal Hilirisasi IPTEKS, 3(1).

Susmiati. Helmizar. Nurdin.A., Putri Z.M., Maisa.E.A., Anand Y., Muthamainah.,Sidaria., Kahairina I. 2019. Pemanfaatan makanan tambahan berbasis diversifikasi dadiah pada ibu hamil dan pelatihan pemantauan status gizi pada petugas kesehatan. Jurnal Hiliriasasi IPTEKS, 2(4a). 